\title{
Keteladanan Sebagai Metode Pendidikan Karakter
}

\author{
Azizah Munawaroh \\ Program Pascasarjana Institut Agama Islam Darussalam (IAID), Ciamis, Jawa Barat \\ Email: azizah_munawwaroh1974@gmail.com
}

Received: December 28, 2018 | Accepted: June 16, 2019

\begin{abstract}
Education includes character education, which is a deliberate process to instill character in students. Character education is very important, because with character, humans will be noble and become special beings compared to other creatures and even fellow human beings. Because of the very importance of character education, the existence of a method to achieve it also becomes very important. This study aims to elaborate exemplary methods in character development. By using library research and reflection methods, this research found that modeling is the most important and most effective character education method provided that: it is comprehensively carried out by educators in each educational environment; conducted together with other educational methods; and shown in three aspects: cognitive, affective, and psychomotor.
\end{abstract}

\begin{abstract}
Abstrak
Pendidikan mencakup di dalamnya pendidikan karakter, yang merupakan proses yang disengaja untuk menanamkan karakter pada peserta didik. Pendidikan karakter sangat penting, karena dengan karakter, manusia akan menjadi mulia dan menjadi makhluk istimewa dibandingkan dengan makhluk yang lain bahkan dengan sesama manusia. Karena sangat pentingnya pendidikan karakter, maka keberadaan metode untuk mencapainya juga menjadi sangat penting. Kajian ini bertujuan untuk mengelaborasi metode keteladanan dalam pengembangan karakter. Dengan menggunakan metode penelitian pustaka dan refleksi, penelitian ini menghasilkan temuan bahwa keteladanan merupakan metode pendidikan karakter yang paling utama dan paling efektif apabila dilakukan secara komprehensif oleh pendidik di setiap lingkungan pendidikan; kemudian dilakukan bersama-sama dengan metode pendidikan yang lain; serta ditunjukkan dalam tiga aspek: kognitif, afektif, dan psikomotor.
\end{abstract}

\section{Keywords}

Islamic education, modeling, character education 


\section{Pendahuluan}

Pendidikan merupakan sebuah proses yang melingkupi seluruh fase kehidupan manusia, mulai dari masa konsepsi sampai dengan kehidupan manusia berakhir. Pendidikan tersebut bertujuan agar manusia dapat berkembang secara optimal pada setiap fase perkembangannya. Jika seseorang sedang berada pada fase merangkak, maka dengan pendidikan, ia harus mampu merangkak dengan baik. Jika seseorang sedang pada fase berjalan, maka dengan pendidikan ia harus mencapai kemampuan berjalan tersebut dengan optimal.

Tidak dapat dilepaskannya pendidikan dari kehidupan manusia menjadikan manusia mendapat predikat dalam bahasa Latin sebagai animal educandum (hewan yang terdidik) atau dalam bahasa Arab sebagai hayawân alnâthiq (hewan yang berakal). Dua predikat tersebut menandakan bahwa pada hakikatnya, manusia adalah hewan yang sama seperti hewan yang lainnya seperti ayam, sapi, kambing, kuda, dan unta. Yang menjadi keistimewaan manusia dan sekaligus membedakan manusia dari hewan yang lainnya adalah adanya pendidikan dan adanya potensi yang berharga yang ada pada diri manusia, yakni akal. Pendidikan dan akal adalah dua hal yang tidak dapat dipisahkan, karena pendidikan hanya diterapkan bagi yang berakal (Biesta, 2010).

Salah satu jenis pendidikan yang harus diberikan kepada manusia adalah pendidikan karakter. Pendidikan karakter adalah segala usaha yang dilakukan oleh pendidik untuk membentuk karakter peserta didik (Supranoto, 2015, p. 36). Dengan karakter, maka keindahan dan kesempurnaan jasmani manusia menjadi lebih indah dan lebih elok. Contohnya berjalan adalah kemampuan jasmani manusia. Berjalannya manusia yang berkarakter akan indah dan membuat orang lain menjadi enak untuk melihatnya, karena gaya berjalannya tidak menunjukkan keangkuhan. Sebaliknya, orang yang berjalan dengan penuh keangkuhan dan menengadahkan wajahnya disertai dengan membusungkan dada, akan membuat orang lain merasa tidak sedap untuk melihatnya (Aeni, 2014).

Secara umum, dalam pendidikan, metode yang dipandang paling utama dan paling efektif adalah keteladanan, yakni pendidik memberikan contoh ucapan atau perbuatan yang baik untuk ditiru oleh peserta didik sehingga peserta didik pun memiliki ucapan atau perbuatan yang baik (Watson, 2019). Sebagai metode yang dipandang paling utama dan paling efektif dalam pendidikan umumnya, tentunya keteladanan juga akan merupakan metode yang dipandang paling utama dan paling efektif dalam pendidikan karakter. Hal ini dapat dipahami, karena pendidikan karakter adalah bagian dari pendidikan. Untuk mengetahui hal itu, dilakukanlah pengkajian yang 
mendalam yang dituangkan dalam judul Keteladanan sebagai Metode Pendidikan Karakter.

\section{Metode}

Kajian ini menggunakan metode penelitian pustaka, dengan menjadikan sejumlah literatur penelitian dan karya-karya para tokoh di bidang pendidikan karakter sebagai sumbernya. Selain itu, penelitian ini juga menggunakan metode refleksi diri peneliti, sehingga pengetahuan, wawasan, dan pengalaman peneliti menjadi salah satu sumber penting dalam kajian tentang metode keteladanan dalam pengembangan karakter ini.

\section{Hasil Kajian dan Pembahasan}

Pendidikan karakter berisi tiga tahapan kegiatan, yaitu menanamkan pengetahuan tentang karakter, perasaan tentang karakter, dan tindakan yang mencerminkan karakter (Novita, 2015). Menilik tiga tahapan kegiatan tersebut, dapat diketahui bahwa sebetulnya pendidikan karakter sama dengan pendidikan jenis lainnya, yakni harus menyentuh tiga ranah kejiwaan manusia, yakni ranah kognitif, afektif, dan psikomotorik (Park \& Peterson, 2006).

Dalam pendidikan karakter, keteladanan diperlukan dalam setiap lingkungan pendidikan, yakni lingkungan keluarga, sekolah, dan masyarakat. Di lingkungan keluarga, keteladanan orang tua sangat diperlukan dalam pendidikan karakter. Keteladanan orang tua menentukan keberhasilan peserta didik dalam proses kepemilikan pengetahuan tentang karakter, perasaan tentang karakter, dan tindakan yang mencerminkan karakter. Orang tua yang tidak mengetahui sopan santun akan menularkan ketidaktahuannya itu kepada anaknya, sehingga akan menciptakan anak yang tidak mengetahui sopan santun pula. Orang tua yang tidak mempunyai perasaan akan pentingnya sopan santun cenderung akan bersikap acuh terhadap anaknya sehingga membiarkan anaknya melakukan perilaku tidak sopan, sehingga anaknya pun tidak memiliki perasaan akan pentingnya sopan santun. Orang tua yang tidak memiliki perilaku tidak sopan akan menampakkan ketidaksopanannya di hadapan anak, sehingga anak setiap saat melihat perilaku tidak sopan kedua orang tuanya, dan akhirnya anak akan meniru perilaku tidak sopan yang senantiasa dilakukan oleh kedua orang tuanya. Hal ini sejalan dengan pendapat yang mengatakan bahwa anak yang memiliki pengetahuan karakter, perasaan karakter, dan tindakan karakter yang rendah disebabkan oleh keteladanan orang tua yang rendah dalam ketiga aspek tersebut (Novita, 2015, p. 184). 
Anak perempuan cenderung mempunyai daya meniru yang lebih baik dari pada anak laki-laki (Novita, 2015). Oleh karena itu, keteladanan orang tua akan lebih efektif dalam pendidikan karakter kepada anak perempuan dibandingkan kepada anak laki-laki. Selain itu, karena menanamkan karakter kepada anak laki-laki dengan metode keteladanan lebih sulit dibandingkan dengan menanamkan karakter kepada anak perempuan, maka implikasinya adalah orang tua tidak cukup hanya dengan mengandalkan keteladanan sebagai metode pendidikan karakter bagi anak laki-laki, tetapi juga orang tua harus menggunakan metode pendidikan yang lainnya.(Lee, Chang, Choi, Kim, \& Zeidler, 2012) Hal ini tidak berarti bahwa dalam pendidikan karakter kepada anak perempuan orang tua tidak perlu menggunakan metode pendidikan yang lain selain keteladanan.

Inti dari keteladanan adalah peniruan, yakni proses meniru peserta didik terhadap pendidik; proses meniru yang dilakukan anak-anak terhadap orang dewasa; proses meniru yang dilakukan anak terhadap orang tuanya; proses meniru murid terhadap gurunya; proses meniru yang dilakukan anggota masyarakat terhadap tokoh masyarakat. Bahwa dalam keteladanan terjadi proses meniru (Suhono \& Utama, 2017).

Adanya proses peniruan dalam metode keteladanan menjadikan keteladanan merupakan metode yang berfungsi konservatif, yakni fungsi melestarikan. Orang tua yang memberikan keteladanan berupa perilaku terpuji kepada anaknya, maka perilaku terpuji tersebut akan tetap ada dan hidup bersama anak itu dengan bentuk yang sama persis. Begitu pula jika seseorang memberi keteladanan berupa perilaku terpuji kepada cucunya, maka perilaku terpuji tersebut akan lestari dan hidup bersama cucunya tersebut dengan bentuk yang sama persis. Maksud sama persis di sini adalah jika perilaku terpuji tersebut berupa sikap menghormati orang lain, maka sikap itulah yang akan tetap lestari bersama orang yang meniru. Begitulah keteladanan menjadikan segala sesuatu, baik ucapan maupun perbuatan, terjaga kelestariannya.

Proses peniruan dalam metode keteladanan dapat terjadi secara disadari maupun tidak disadari. Dalam keteladanan terjadi proses meniru, baik secara sadar maupun tidak sadar. Peniruan yang tidak disadari adalah peniruan yang terjadi di mana orang yang meniru merasa tidak sadar bahwa ia sesungguhnya sedang meniru sebuah objek yang senantiasa ia kagumi, ia perhatikan, ia lihat, dan ia dengar (Suhono \& Utama, 2017). Peniruan yang tidak disadari terjadi jika yang ditiru tidak mengharuskan kepada peniru untuk meniru apa yang diucapkan atau dilakukannya. Contoh peniruan yang tidak disengaja adalah peserta didik yang senantiasa melihat gurunya berpenampilan rapi, maka secara tidak sadar peserta didik akan mengikuti penampilan rapi sebagaimana yang 
ditampilkan gurunya. Walaupun guru tersebut tidak memberikan perintah kepada peserta didiknya untuk berpenampilan rapi.

Adapun peniruan yang dilakukan secara sengaja adalah peniruan yang disertai dengan adanya pengetahuan dan perasaan mengenai pentingnya sesuatu yang ditiru atau manfaat dari sesuatu yang ditiru pada diri peniru. Peserta didik yang sudah mengetahui bahwa sebuah karakter itu penting dan bermanfaat dalam kehidupan, maka ia akan secara sengaja meniru karakter tersebut dari pendidik. Peserta didik yang sudah merasakan pentingnya sebuah karakter, ia akan secara sadar dan sengaja meniru karakter tersebut dari pendidik. Dengan kata lain, peniruan yang disengaja dalam keteladanan dapat terjadi jika peniru yang dalam hal ini peserta didik sudah memiliki pengetahuan karakter (character knowing) dan perasaan karakter (character feeling) (Narvaez \& Lapsley, 2008).

Secara formal di sekolah, pengetahuan karakter dapat timbul pada peserta didik melalui pembelajaran yakni pembelajaran yang berkaitan dengan karakter, seperti pada pembelajaran Pendidikan Kewarganegaraan. Melalui pembelajaran ini, peserta didik dapat mengetahui manfaat dan pentingnya karakter-karakter bangsa untuk dimiliki dan menjadi bagian dari kepribadiannya.

Secara tidak formal di lingkungan keluarga dan masyarakat, pengetahuan karakter dapat timbul pada peserta didik melalui nasihat. Nasihat merupakan metode pendidikan yang bersifat verbal, di mana pendidik memberikan arahan kepada peserta didik, misalnya orang tua memberikan nasihat kepada anaknya, atau guru memberikan nasihat kepada peserta didiknya. Melalui nasihat, peserta didik menjadi tahu dan akan merasakan pentingnya karakter untuk dimiliki.

Berdasarkan uraian mengenai peniruan yang dilakukan secara disadari, dapat disimpulkan bahwa peniruan secara disadari terjadi dengan bantuan metode pendidikan yang lain, seperti pembelajaran dan nasihat. Hal ini sekaligus menandakan bahwa keteladanan sebagai metode pendidikan karakter tidak dapat berdiri sendiri tanpa bantuan metode pendidikan karakter yang lainnya.

Oleh karena inti dari keteladanan adalah peniruan, maka hasilnya adalah "sama dengan", yakni peniru sama dengan yang ditiru; perilaku baik peserta didik sama dengan perilaku baik gurunya; tutur kata peserta didik yang sopan sama dengan tutur kata sopan gurunya; perilaku baik anak sama dengan perilaku baik kedua orang tuanya; ucapan lembut anak sama dengan ucapan lembut kedua orang tuanya. Dengan kata lain, peserta didik adalah cerminan dari pendidiknya; karakter peserta didik adalah cerminan karakter pendidiknya (Narvaez \& Lapsley, 2008). 
Keteladanan sebagai metode pendidikan karakter dapat digunakan untuk mengidentifikasi faktor penyebab baik-buruknya karakter seseorang (Banks, 2009). Misalnya, jika peserta didik tidak memiliki karakter peduli lingkungan, maka dapat dipastikan salah satu penyebabnya adalah guru sebagai pendidiknya juga tidak memiliki karakter tersebut. Jika seorang anak tidak memiliki karakter bekerja keras, maka dapat dipastikan bahwa salah satu penyebabnya adalah kedua orang tuanya tidak memiliki karakter tersebut, atau jika seorang individu tidak memiliki karakter cinta damai misalnya, maka dapat dipastikan bahwa para pendidiknya di dalam tri pusat pendidikan (keluarga, sekolah, dan masyarakat) juga tidak memiliki karakter tersebut.

Di Indonesia, karakter yang harus ditanamkan oleh pendidik kepada peserta didik berjumlah delapan belas, yaitu: religius, jujur, toleransi, disiplin, kerja keras, kreatif, mandiri, demokratis, ingin tahu, semangat kebangsaan, cinta tanah air, menghargai prestasi, komunikatif, cinta damai, gemar membaca, peduli lingkungan, peduli sosial, dan tanggung jawab (Hendriana $\&$ Jacobus, 2016, p. 29). Untuk dapat menerapkan metode keteladanan dalam pendidikan karakter, pendidik, baik guru maupun orang tua serta masyarakat, harus terlebih dahulu memiliki karakter-karakter tersebut dan menampilkannya di hadapan peserta didik. Untuk dapat memberikan pendidikan karakter religius misalnya, maka pendidik harus merupakan orang yang religius yang religiusitasnya senantiasa ditampilkan dalam kehidupan sehari-hari, termasuk di hadapan peserta didik. Dengan demikian, keteladanan sebagai metode pendidikan karakter hanya dapat digunakan oleh pendidik yang berkarakter.

Ditampilkannya karakter-karakter sebagaimana dikemukakan di atas harus dilakukan oleh pendidik secara komprehensif. Maksudnya, pendidik harus mampu menampilkan karakter-karakter yang hendak ditanamkan kepada peserta didik dalam berbagai lingkungan pendidikan. Hal ini hanya dapat dilakukan oleh pendidik yang sudah memiliki karakter-karakter tersebut secara terinternalisasi, sehingga karakter-karakter tersebut sudah menjadi bagian dari kepribadiannya. Hal ini berarti bahwa seorang pendidik harus memberikan keteladanan di mana pun dan kapan pun (Hidayat, 2015, p. 149).

Lingkungan keluarga diyakini sangat potensial sebagai lingkungan pendidikan dengan metode keteladanan (Raharjo, 2017, p. 109). Keluarga merupakan sumber keteladanan yang pertama dan utama. Sebagai sumber keteladanan yang pertama karena anak pertama kali menerima keteladanan di lingkungan tersebut, yakni dari kedua orang tuanya. Sebagai sumber keteladanan yang utama karena keluarga adalah inti dari lingkungan sosial.

Selain sebagai sumber keteladanan, keluarga juga adalah sebagai lingkungan utama yang menerima akibat dari keteladanan, termasuk dalam 
pendidikan karakter. Jika keteladanan dari kedua orang tua baik, maka merekalah yang pertama kali akan merasakan karakter baik yang dimiliki anaknya (Raharjo, 2017, p. 106). Jika keteladanan dari kedua orang tua tidak baik, maka mereka pulalah yang pertama kali akan merasakan karakter buruk yang dimiliki anaknya.

Peran keteladanan orang tua di lingkungan orang tua amat menentukan keberhasilan pendidikan karakter di lingkungan sekolah dan lingkungan masyarakat. Dengan demikian, untuk mempermudah pencapaian pendidikan karakter pada peserta didik, sekolah harus bekerja sama dengan orang tua (Saripah, 2016, p. 21). Tanpa kerja sama tersebut, pendidikan karakter akan sulit untuk mencapai hasil yang maksimal.

Untuk membentuk lingkungan keluarga dengan kondisi demikian, maka orang tua harus terdidik. Orang tua harus memiliki pendidikan yang tinggi baik secara formal maupun informal, sehingga ia memiliki pemahaman yang tinggi tentang pentingnya pendidikan karakter pada anak. Dengan pemahaman ini, diharapkan kedua orang tua mampu mengaplikasikan pendidikan karakter terhadap anak-anaknya.

Pada zaman sekarang, untuk mendapatkan peran orang tua yang maksimal dalam pendidikan karakter di lingkungan keluarga tampaknya agak sulit, karena berbenturan dengan banyaknya orang tua (ayah dan ibu) yang lebih disibukkan dengan pekerjaan dan karier mereka, sehingga orang tua memiliki waktu yang sedikit untuk berinteraksi dengan anak di rumah, padahal keteladanan diperoleh melalui interaksi yang intensif antara orang tua dengan anak.

Kesibukan orang tua sebagaimana dikemukakan di atas menjadikan banyak orang tua mempekerjakan baby sitter untuk mengasuh anak-anak mereka di rumah yang masih usia balita dan usia awal sekolah dasar. Ada juga orang tua yang membiarkan anaknya tanpa pengasuh dan baby sitter karena anaknya sudah berada pada usia sekolah, sehingga anaknya sepulang sekolah sering berada di luar rumah tanpa pengawasan dari orang tua; apakah ia bergaul dengan teman yang baik yang kondusif untuk membantu pendidikan karakter atau sebaliknya bergaul dengan teman-temannya yang berperilaku tidak baik.

Solusi untuk mengatasi keadaan demikian adalah kalaupun orang tua harus menyerahkan pengasuhan anak kepada baby sitter, maka baby sitter tersebut harus dipilih secara selektif. Orang tua harus memilih baby sitter yang sehat badannya agar tidak menularkan penyakit kepada anak. Orang tua juga harus memilih baby sitter yang mengetahui tentang kesehatan dan gizi anak agar ia mampu menyajikan makan yang sehat dan sempurna untuk anak. Orang tua harus mempekerjakan baby sitter yang senantiasa bertutur kata 
lembut dan santun agar anak menirunya sehingga anak pun bertutur kata yang lembut dan sopan. Orang tua juga harus mempekerjakan baby sitter yang berkarakter baik agar ia menjadi teladan yang baik bagi anak sehingga anak pun mempunyai karakter yang baik.

Adapun jika orang tua tidak mempekerjakan pengasuh atau baby sitter karena anaknya sudah tidak tergolong usia balita dan kanak-kanak awal, maka sebaiknya orang tua membuat strategi untuk mengawasi pergaulan anaknya, sehingga ia bisa mengetahui apa yang dikerjakan oleh anaknya sepanjang hari; apakah anaknya mengerjakan pekerjaan yang baik atau buruk, dan bersama siapa anaknya bergaul sepanjang hari; apakah bergaul dengan teman yang berkarakter baik atau bergaul dengan teman-temannya yang berkarakter tidak baik. Hal ini dapat dipahami karena pengawasan adalah termasuk salah satu metode pendidikan, selain keteladanan, nasihat, ganjaran, dan hukuman.

Di lingkungan sekolah, pendidikan karakter sangat penting untuk didukung oleh guru. Dalam pendidikan karakter di sekolah, guru berperan penting sebagai figur teladan (Das, 2018). Berhasil tidaknya pendidikan karakter di sekolah akan sangat bergantung pada adanya figur teladan tersebut, yang memberi keteladanan dalam berbagai aspek, baik kognitif, afektif, maupun psikomotor. Dalam aspek kognitif, guru harus memiliki pengetahuan yang mendalam yang ditampakkannya di hadapan peserta didik. Dalam aspek afektif, guru harus memiliki sikap yang mulia yang ditampakkannya di hadapan peserta didik. Dalam aspek psikomotor, guru harus menguasai keterampilan-keterampilan dengan sempurna dan menampakkannya di hadapan peserta didik. Penguasaan dan penampakan kognitif, afektif, dan psikomotor tersebut sangat penting agar dapat dilihat, didengar, lalu ditiru oleh peserta didik.

Figur teladan di sekolah sebetulnya bukan hanya guru sebagai pendidik, tetapi juga seluruh tenaga kependidikan. Guru mungkin menjadi satu-satunya figur teladan di sekolah jika sekolah tersebut masih belum memiliki staf seperti operator sekolah dan penjaga perpustakaan sebagaimana terjadi pada jenjang Sekolah Dasar (SD)/Madrasah Ibtidaiyah (MI) tahun 1990-an. Akan tetapi, jika organisasi sekolah sudah dikelola dengan staffing yang memadai sehingga di dalamnya terdapat operator sekolah, pustakawan, dan staf-staf lainnya, maka figur teladan bagi peserta didik di sekolah bukan hanya guru, tetapi juga mencakup seluruh staf. Semua unsur ini, yakni guru dan seluruh staf atau tenaga kependidikan, harus memiliki dan menampakkan keteladanan di hadapan peserta didik.

Namun, perlu ditegaskan bahwa sejatinya figur sentral keteladanan di sekolah tetaplah guru (Rodin, 2013, p. 161). Hal ini dapat dipahami karena guru adalah orang yang paling intensif berkomunikasi dan berinteraksi dengan 
peserta didik. Selama di sekolah, gurulah yang paling lama berinteraksi dengan peserta didik dibandingkan dengan warga sekolah yang lainnya, sehingga sangat logis jika pengaruh keteladanannya lebih besar dibandingkan dengan pengaruh keteladanan dari warga sekolah yang lain.

Kekurangan pendidikan formal di sekolah selama ini adalah pendidikan terlalu terfokus pada pencapaian dan pemenuhan aspek kognitif, sedangkan pengembangan soft skill yang merupakan bagian utama dari pendidikan karakter kurang mendapat perhatian. Hal ini tampak pada proses pembelajaran yang menekankan pada hasil yang berupa pencapaian aspek kognitif, dan bahkan aspek kognitif menjadi satu-satunya penentu kelulusan peserta didik dari lembaga pendidikan (Judiani, 2010, p. 288). Keadaan ini diperbaiki dengan tidak dijadikannya nilai Ujian Nasional sebagai penentu kelulusan, tetapi kelulusan peserta didik ditentukan dengan aspek akhlak peserta didik setelah diberlakukannya Kurikulum Tingkat Satuan Pendidikan (KTSP).

Keadaan tersebut di atas lebih diperbaiki lagi setelah diberlakukannya Kurikulum 2013 yang lebih memberi porsi yang besar kepada peserta didik untuk aktif mengembangkan kognitif, afektif, dan psikomotor dalam belajar dan guru hanya berperan besar sebagai fasilitator. Di dalam Kurikulum 2013 terdapat pendekatan saintifik yang menuntut peserta didik bersikap mandiri, bekerja keras, gemar membaca, dan menanya untuk melakukan untuk memperoleh pengetahuan, sikap, dan keterampilan.

Di sekolah, metode keteladanan dapat diterapkan dalam pendidikan karakter tidak hanya dalam mata pelajaran Pendidikan Agama Islam dan Pendidikan Kewarganegaraan, tetapi keteladanan dapat diintegrasikan ke dalam setiap pembelajaran, baik pembelajaran Pendidikan Agama Islam, pembelajaran Pendidikan Kewarganegaraan maupun pembelajaran mata pelajaran lain yang secara kasat mata nama mata pelajarannya tidak memiliki muatan karakter sekalipun (Zubaedi, 2012, p. 11), seperti mata pelajaran sejarah yang dapat "disusupi" pendidikan karakter oleh guru mulai dari tahap penyusunan Rencana Pelaksanaan Pembelajaran (RPP) dengan berbagai komponennya seperti tujuan, materi, media dan metode, pelaksanaan pembelajaran, dan penilaian hasil pembelajaran (Hasan, 2012, p. 81).

Adanya keharusan untuk menanamkan pendidikan karakter melalui metode keteladanan ke dalam setiap mata pelajaran menunjukkan bahwa setiap guru, baik guru mata pelajaran yang nomenklaturnya memiliki muatan karakter maupun mata pelajaran yang nomenklaturnya tidak memiliki muatan karakter, harus memiliki kompetensi kepribadian; setiap guru harus memiliki keteladanan.

Selain itu, adanya keharusan untuk menanamkan pendidikan karakter melalui metode keteladanan ke dalam setiap mata pelajaran secara terintegrasi 
juga menunjukkan bahwa kewajiban mendidik karakter adalah kewajiban setiap guru tanpa memandang jenis mata pelajaran yang dia ampu di sekolah. Hal ini dapat dipahami karena memang pendidikan karakter adalah suatu pendidikan yang memerlukan kerjasama dari berbagai pihak dan jenis pendidikan yang tidak mudah untuk mencapai keberhasilannya.

Keteladanan sebagai metode pendidikan karakter tidak hanya harus ditunjukkan oleh pendidik di lingkungan keluarga, sekolah, dan masyarakat, tetapi juga harus ditunjukkan oleh teman sebaya dan media massa (Wening, 2012, p. 55). Dengan demikian, lingkungan pada zaman sekarang tidak hanya sebatas pada keluarga, sekolah, dan masyarakat yang biasa disebut dengan tri pusat pendidikan, tetapi lebih luas dari itu. Adanya perluasan lingkungan pendidikan ini adalah pengaruh perkembangan ilmu pengetahuan dan teknologi yang berpengaruh terhadap hasil pendidikan. Media massa pada zaman dahulu keberadaannya tidak ada, dan kalaupun ada pada masa berikutnya, perkembangannya kurang berpengaruh terhadap hasil pendidikan.

Lingkungan pergaulan dengan teman sebaya juga merupakan lingkungan tambahan yang berpengaruh terhadap pembentukan karakter seseorang. Adanya teman sebaya sebagai lingkungan sosial yang berpengaruh terhadap pembentukan karakter seseorang berdampak pada harus berhati-hatinya seorang anak untuk memilih teman bergaul. Selain itu, hal ini juga berdampak pada orang tua agar mengawasi secara ketat mengawasi pergaulan sehari-hari anak mereka dengan teman sebayanya, sehingga orang tua tidak kecolongan membiarkan anaknya bergaul dengan teman-teman sebaya mereka yang mempunyai karakter yang buruk.

Adanya teman sebaya sebagai lingkungan sosial yang berpengaruh terhadap pendidikan karakter menandakan bahwa proses peniruan tidak hanya dilakukan oleh anak terhadap orang yang lebih dewasa, tetapi juga dilakukan oleh anak terhadap sesama temanya yang sebaya. Dengan kata lain, seorang teman dapat menjadi teladan bagi seorang anak, yang pengaruhnya tidak kalah dengan keteladanan yang diberikan oleh orang tua atau guru.

Pendidikan karakter bukanlah sekadar membekali peserta didik pengetahuan akan karakter, tetapi juga menanamkan karakter itu pada diri peserta didik sehingga peserta didik menjadi bagian yang tak terpisahkan dari kepribadian peserta didik. Jika hanya aspek pengetahuan (pengetahuan karakter) yang ditanamkan kepada peserta didik, maka hanya satu pertiga dari ranah kejiwaan peserta didik yang terisi, karena dua bagian lagi yakni perasaan karakter dan tindakan karakternya belum terisi. Jika hanya pengetahuan karakter dan perasaan karakter yang ditanamkan oleh pendidik kepada peserta didik, maka hanya dua pertiga dari seluruh ranah kejiwaan peserta didik yang terisi, sedangkan satu bagian lagi, yakni tindakan karakter, tidak ditanamkan. 
Seluruh ranah kejiwaan peserta didik baru akan penuh terisi jika pengetahuan, perasaan, dan tindakan karakter ditanamkan seluruhnya kepada peserta didik (Rodin, 2013, p. 161).

Keteladanan tidak hanya dapat ditampilkan oleh orang yang ada secara fisik, tetapi juga dapat diberikan oleh orang yang keberadaannya sudah tidak ada di dunia (Chaerulsyah, 2014, p. 4), seperti keteladanan Nabi Muhammad, keteladanan para sahabat, keteladanan para wali Allah, keteladanan orangorang yang saleh, keteladanan para pahlawan pejuang kemerdekaan Indonesia. Keteladanan mereka dapat dihidupkan kembali dan dihadirkan kepada peserta didik dengan bantuan para pendidik melalui metode kisah dan nasihat.

Keteladanan memerlukan metode pendidikan lain. Sebagai contoh keteladanan dapat dipertajam dengan metode kisah. Metode kisah dapat berfungsi sebagai pelengkap bagi keteladanan, khususnya keteladanan dari orang yang sudah wafat. Selain metode kisah, keteladanan juga dapat dilengkapi dengan metode nasihat, terutama jika dikhawatirkan peserta didik tidak memahami bentuk keteladanan yang diberikan oleh pendidik.

Diperlukannya metode pendidikan yang lain untuk melengkapi metode keteladanan yang menyatakan bahwa strategi pembelajaran pendidikan karakter di sekolah dapat dilakukan melalui empat cara, yaitu: keteladanan (modelling), pembelajaran (instruction), penguatan (reinforcement), dan pembiasaan (habituating) (Sudrajat, 2011).

Diperlukannya metode pendidikan yang lain untuk melengkapi metode keteladanan dalam pendidikan karakter menunjukkan bahwa pendidikan karakter adalah sebuah proses yang sulit, yang tidak cukup hanya dengan mengandalkan satu metode pendidikan, tetapi membutuhkan metode pendidikan yang lain. Dalam pendidikan karakter, karakter yang buruk ibarat musuh yang sangat berat yang harus dikepung dari empat penjuru mata angin untuk dapat melumpuhkanya. Begitulah pendidikan karakter harus dilakukan dengan menggunakan persenjataan dan strategi berupa metode pendidikan yang lengkap agar mencapai keberhasilan.

Keteladanan menjadi urgen untuk digunakan sebagai metode pendidikan karena mempunyai landasan naqli, yakni Alquran dan hadis. Dalil naqli tentang keteladanan antara lain terdapat dalam Alquran surat al-Ahzab ayat 21 yang menyatakan bahwa sesungguhnya telah terdapat keteladanan yang baik pada diri Rasulullah saw.

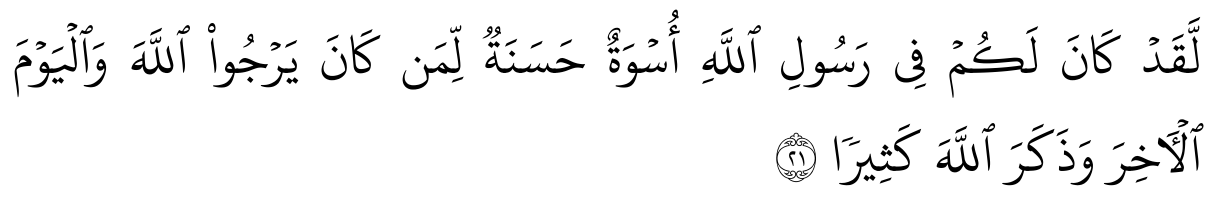


Sesungguhnya telah ada pada (diri) Rasulullah itu suri teladan yang baik bagimu (yaitu) bagi orang yang mengharap (rahmat) Allah dan (kedatangan) hari kiamat dan dia banyak menyebut Allah" (Q.S. AlAhzab, 33: 21).

Selain menurut landasan naqli, secara filosofis, manusia membutuhkan seorang figur teladan untuk ditiru (Maya, 2017, p. 14). Hal ini dapat dipahami karena meniru merupakan salah satu naluri alamiah dan salah satu cara belajar manusia sebagaimana Qabil yang meniru perilaku burung gagak yang menguburkan burung gagak yang lain yang dibunuh olehnya. Begitu pulalah yang dilakukan oleh Qabil dalam memperlakukan jasad saudaranya, Habil, yang ia bunuh. Qabil menggali lubang kemudian jasad Habil dimasukkan ke dalamnya. Ini sama persis dengan yang dilakukan burung gagak yang ia lihat. Firman Allah:

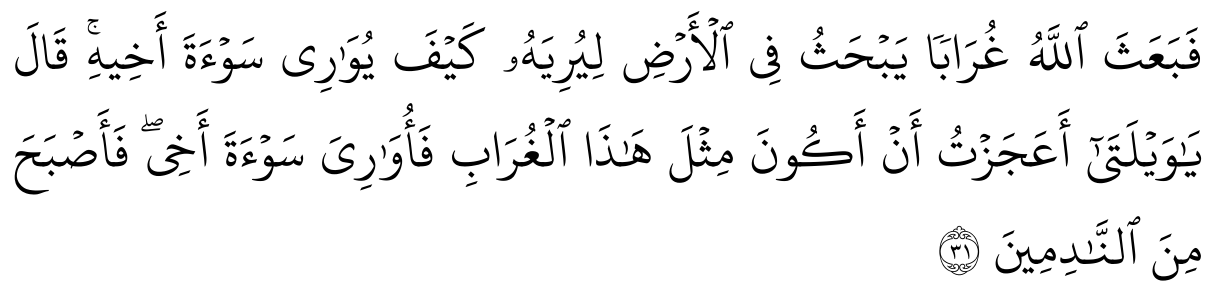

Kemudian Allah menyuruh seekor burung gagak menggali-gali di bumi untuk memperlihatkan kepadanya (Qabil) bagaimana seharusnya menguburkan mayat saudaranya. Qabil berkata: "Aduhai celaka aku, mengapa aku tidak mampu berbuat seperti burung gagak ini, lalu aku dapat menguburkan mayat saudaraku ini ?" Karena itu jadilah dia seorang di antara orang-orang yang menyesal. (Q.S. Al-Maidah, $5: 31$ ).

Figur teladan yang paling ideal adalah Nabi Muhammad saw., dan satu tingkat ideal di bawahnya adalah para sahabat (Maya, 2017, p. 14). Idealnya Nabi Muhammad saw. sebagai figur teladan bagi seluruh umat manusia adalah karena ia adalah orang yang paling sempurna di antara seluruh manusia, bahkan di antara para nabi sekalipun. Kesempurnaan ini tidak hanya dalam bentuk fisik, tetapi juga dalam akhlak sehingga Allah swt. berfirman dalam Alquran surat al-Qalam ayat 4 yang intinya Nabi Muhammad saw. memiliki akhlak yang luhur.

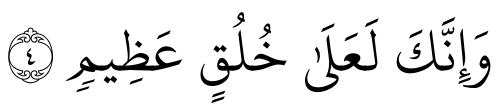

"Dan sesungguhnya kamu benar-benar berbudi pekerti yang agung" (Q.S. Al-Qalam, 68: 4). 
Keteladanan membutuhkan komprehensivitas atau kesatupaduan antara pendidik di berbagai lingkungan, baik lingkungan keluarga, sekolah, maupun masyarakat (Cahyaningrum, 2017, p. 210). Untuk mewujudkan kesatuapaduan itu, diperlukan kerjasama antarpendidik di tiga lingkungan pendidikan tersebut. Untuk mewujudkan kerjasama tersebut, diperlukan kesamaan visi dan pandangan antarpendidik di tiga lingkungan pendidikan tersebut. Kesamaan visi dan pandangan yang dimaksud adalah kesamaan visi dan pandangan tentang pentingnya memberikan keteladanan dalam rangka penanaman karakter kepada anak. Dengan demikian, hal pertama yang harus dilakukan adalah mewujudkan kesamaan visi dan pandangan pada para pendidik setiap lingkungan pendidikan.

Penerapan keteladanan sebagai metode pendidikan karakter harus disesuaikan dengan fase perkembangan anak. Namun, secara umum, keteladanan sebagai metode pendidikan karakter adalah metode yang cocok untuk ditampilkan oleh pendidik di hadapan peserta didik dengan segala fase perkembangan, mulai dari kanak-kanak sampai dengan lanjut usia. Hanya saja, jika melihat fase perkembangan anak, maka ada karakter-karakter tertentu yang sangat cocok untuk ditanamkan pada anak pada fase perkembangan tertentu. Contohnya adalah karakter tanggung jawab, kepedulian sosial, dan kemandirian cocok untuk ditanamkan oleh pendidik kepada peserta didik yang berada pada usia Sekolah Dasar, yakni pada fase kanak-kanak awal sampai fase kanak-kanak akhir (Aeni, 2014, p. 58). Ketepatan dan kecocokan materi keteladanan dengan fase perkembangan anak yang menjadi peserta didik akan menambah efektivitas pencapaian tujuan pendidikan karakter.

Untuk itulah, pendidik, baik di rumah, di sekolah, maupun di lingkungan masyarakat harus memahami psikologi perkembangan anak yang di dalamnya antara lain terdapat materi tentang fase-fase perkembangan anak dan tugas-tugas perkembangannya, sehingga tidaklah mengherankan bahwa pemahaman terhadap peserta didik dijadikan sebagai salah satu bagian dari kompetensi pedagogik guru.

\section{Kesimpulan}

Berdasarkan pembahasan di muka, dapat diperoleh kesimpulan bahwa keteladanan dapat dijadikan sebagai metode yang utama dalam pendidikan karakter, yang dalam penerapannya memerlukan metode pendidikan yang lain. Selain itu, keteladanan sebagai metode pendidikan karakter harus ditunjukkan oleh pendidik di setiap lingkungan pendidikan, yakni keluarga, sekolah, masyarakat, teman sebaya, dan media massa. Keteladanan juga harus ditunjukkan secara komprehensif meliputi aspek kognitif, afektif, dan 
psikomotor, karena pendidikan karakter menyentuh tiga aspek tersebut, yakni character knowing (pengetahuan karakter), character feeling (perasaan karakter), dan character action (tindakan karakter).

\section{DAFTAR PUSTAKA}

Aeni, A. N. (2014). Pendidikan Karakter untuk Siswa SD dalam Perspektif Islam. Mimbar Sekolah Dasar, 1(1), 50-58.

Banks, J. A. (2009). Multicultural Education: Characteristics and Goals. In J. A. Banks \& C. A. McGee (Eds.), Multicultural Education: Issues and Perspectives. New York: John Wiley and Sons.

Biesta, G. J. J. (2010). Why "What Works" Still Won't Work: From EvidenceBased Education to Value-Based Education. Studies in Philosophy and Education, 29(5), 491-503. https://doi.org/10.1007/s11217-010-9191-x

Cahyaningrum, E. S. et al. (2017). Pengembangan Nilai-nilai Karakter Anak Usia Dini melalui Pembiasaan dan Keteladanan. Jurnal Pendidikan Anak, 6(2), 203-213.

Chaerulsyah, E. M. (2014). Persepsi Siswa tentang Keteladanan Pahlawan Nasional untuk Meningkatkan Semangat Kebangsaan. Indonesian Journal of History Education, 3(1), 1-5.

Das, S. W. H. (2018). The Character Education of Early Childhood: Brain-Based Teaching Approach. https://doi.org/10.2991/amca-18.2018.8

Hasan, S. H. (2012). Pendidikan Sejarah untuk Memperkuat Pendidikan Karakter. Paramita, 22(1), 81-95.

Hendriana, E. C., \& Jacobus, A. (2016). Implementasi Pendidikan Karakter di Sekolah melalui Keteladanan dan Pembiasaan. Jurnal Pendidikan Dasar Indonesia, 1(2), 25-29.

Hidayat, N. (2015). Metode Keteladanan dalam Pendidikan Islam. Ta'allum, 3(2), 135-150.

Judiani, S. (2010). Implementasi Pendidikan Karakter di Sekolah Dasar melalui Penguatan Pelaksanaan Kurikulum. Jurnal Pendidikan Dan Kebudayaan, 16(3), 280-289.

Lee, H., Chang, H., Choi, K., Kim, S. W., \& Zeidler, D. L. (2012). Developing Character and Values for Global Citizens: Analysis of PreService Science Teachers' Moral Reasoning on Socioscientific Issues. International Journal of Science Education, 34(6), 925-953. https://doi.org/10.1080/09500693.2011.625505

Maya, R. (2017). Pemikiran Pendidikan Muhammad Quthb tentang Metode 
Keteladanan (Al-Tabiyyah bi al-Qudwah). Jurnal Edukasi Islami: Jurnal Pendidikan Islam, 6(11), 1-16.

Narvaez, D., \& Lapsley, D. K. (2008). Teaching Moral Character: Two Alternatives for Teacher Education. The Teacher Educator, 43(2), 156172. https://doi.org/10.1080/08878730701838983

Novita, et al. (2015). Pengaruh Iklim Keluarga dan Keteladanan Orang Tua terhadap Karakter Remaja Perdesaan. Jurnal Pendidikan Karakter, 5(2), 184-194.

Park, N., \& Peterson, C. (2006). Moral Competence and Character Strengths among Adolescents: The Development and Validation of the Values in Action Inventory of Strengths for Youth. Journal of Adolescence, 29(6), 891-909. https://doi.org/10.1016/j.adolescence.2006.04.011

Raharjo, S. T. (2017). Mewujudkan Pembangunan Kesejahteraan Sosial melalui Keteladanan Nasional dan Keluarga. Share: Social Work Journal, 5(2), 196-208.

Rodin, R. (2013). Urgensi Keteladanan bagi Seorang Guru Agama (Kajian terhadap Metode Pendidikan Islam). Cendekia, 11(1), 149-162.

Saripah, I. (2016). Peran Orang Tua dan Keteladanan Guru dalam Peningkatan Mutu Pendidikan Akhlak Siswa Madrasah Ibtidaiyah. Studia Didaktika: Jurnal Ilmiah Pendidikan, 10(2), 19-32.

Sudrajat, A. (2011). Mengapa Pendidikan Karakter? Jurnal Pendidikan Karakter, 1(1), 47-58.

Suhono, \& Utama, F. (2017). Keteladanan Orang Tua dan Guru dalam Pertumbuhan dan Perkembangan Anak Usia Dini (Perspektif Abdullah Nashih Ulwan Kajian Kitab Tarbiyyah al-Aulad fi al-Islam). Elementary, 3(2), 107-119.

Supranoto, H. (2015). Implementasi Pendidikan Karakter Bangsa dalam Pembelajaran SMA. Jurnal Promosi: Jurnal Pendidikan Ekonomi UM Metro, 3(1), 36-49.

Watson, L. (2019). Educating for Inquisitiveness: A Case Against Exemplarism for Intellectual Character Education. Journal of Moral Education. https://doi.org/10.1080/03057240.2019.1589436

Wening, S. (2012). Pembentukan Karakter Bangsa melalui Pendidikan Nilai. Jurnal Pendidikan Karakter, 2(1), 55-66.

Zubaedi. (2012). Desain Pendidikan Karakter Konsepsi dan Aplikasinya dalam Dunia Pendidikan. Jakarta: Kencana. 
